\title{
Polypoid Gastric Heterotopia of Colon
}

\author{
Marcela Adriana Duran Alvarez ${ }^{\mathrm{a}} \quad$ Carla Noemi Tafur Sanchez ${ }^{\mathrm{b}}$ \\ ${ }^{a}$ Department of Pathology, Hospital de Medina del Campo, Valladolid, Spain; ${ }^{b}$ Department of Gastroenterology, \\ Hospital de Medina del Campo, Valladolid, Spain
}

Keywords

Gastric heterotopia - Gastric mucosa - Colonic polyps

\section{Heterotopia gástrica polipóide do colon}

\section{Palavras Chave}

Heterotopia gástrica · Mucosa gástrica · Pólipos

colónicos

\section{Clinical Case}

A 67-year-old male presented to the Emergency Department with watery diarrhea of 2 days' duration with intermittent rectal bleeding without fever, vomiting, or abdominal pain. His clinical history included the diagnosis of irritable bowel 10 years ago, hypertension, ischemic cardiopathy, dyslipidemia, abdominal aneurysm, and hiatal hernia. He was in treatment with furosemide, fenofibrate, salicylate, and omeprazole. Physical examination was unremarkable except for the presence of hemorrhoids, although rectal touch was negative. Blood test excluded anemia or signs of an infectious disease. For the first time, the patient underwent a colonoscopy

\section{KARGER}

E-Mail karger@karger.com www.karger.com/pjg
(C) 2019 Sociedade Portuguesa de Gastrenterologia Published by S. Karger AG, Basel

Karcer

Upen access

This article is licensed under the Creative Commons AttributionNonCommercial-NoDerivatives 4.0 International License (CC BYNC-ND) (http://www.karger.com/Services/OpenAccessLicense). Usage and distribution for commercial purposes as well as any distribution of modified material requires written permission. that identified two polyps. One was a tubular adenoma with low-grade dysplasia, without signs of bleeding, measuring $3 \mathrm{~mm}$ in diameter, located at $40 \mathrm{~cm}$ from the anal verge. The second was a sessile nonulcerated polyp, centrally depressed (Fig. 1), measuring $20 \mathrm{~mm}$, located at $20 \mathrm{~cm}$ from the anal verge. Histologically, this polyp was entirely covered by an intact gastric oxyntic mucosa with all the elements found in normal orthotopic oxyntic mucosa (Fig. 2), sharply demarcated from the surrounding colonic mucosa (Fig. 3). The core of the polyp showed loose connective tissue with a fine vascular network without signs of bleeding or thrombosis. Neither epithelial dysplasia nor malignancy were detected. The diagnosis was polypoid gastric heterotopia of the colon $(\mathrm{GH})$.

\section{Discussion}

The presence of heterotopic gastric mucosa in the colon is a rare finding of unclear pathogenesis probably related to a developmental error in gastric positioning and migration along the early embryonic life [1]. Microscopically, almost all reported cases are of oxyntic type [1-4]. All the normal components of oxyntic mucosa are present and functioning [1-4]. In contrast, gas- 


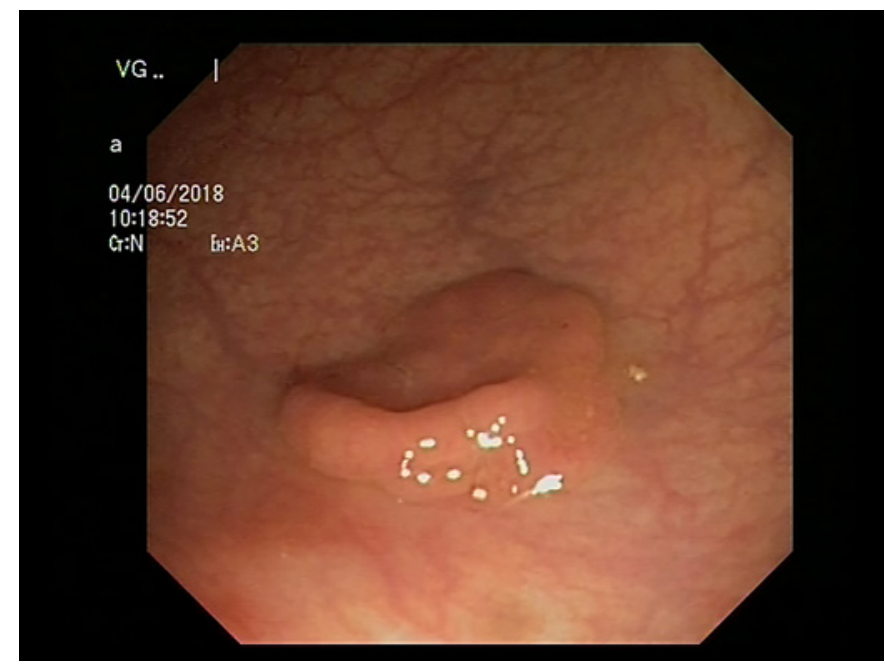

Fig. 1. Sessile polyp with central depression without signs of bleeding.

tric metaplasia is usually of pyloric type and arises in a chronic inflammatory background by reprogramming differentiation of reserve cells in the colonic crypts; therefore, the structure of normal gastric mucosa is not present $[1,2]$.

This entity has been described in children and adults. Episodic diarrhea, rectal bleeding and abdominal pain are common symptoms. Often, the patients were diagnosed as having irritable bowel $[1,2]$. GH can be multifocal and accompanied by other intestinal and extraintestinal malformations [1,2]. The diagnosis of colonic GH should prompt the search for other intestinal lesions by abdominal computed tomography, capsule endoscopy, and/or technetium- $99 \mathrm{~m}$ pertechnetate scan. In some cases, the source of bleeding was identified in the surrounding colonic mucosa as a corrosive effect of acid secretion [2]. In our case, no other lesions were detected on colonoscopy, and we considered that hemorrhoids could be the source of bleeding. Our patient was in treatment with omeprazole because of his hiatal hernia. We suspect that a fault in the omeprazole treatment could precipitate this episode.

Treatment of polypoid GH is endoscopic resection. In one reported case, treatment with a $\mathrm{H}_{2}$-antagonist was used with success in the control of bleeding [3]. Colonic adenocarcinoma in GH has been described in the literature [4], but the link between these two entities is unclear. No other lesions were found in the workup. Omeprazole was not maintained. Twelve months after polypectomy, the patient is doing well.

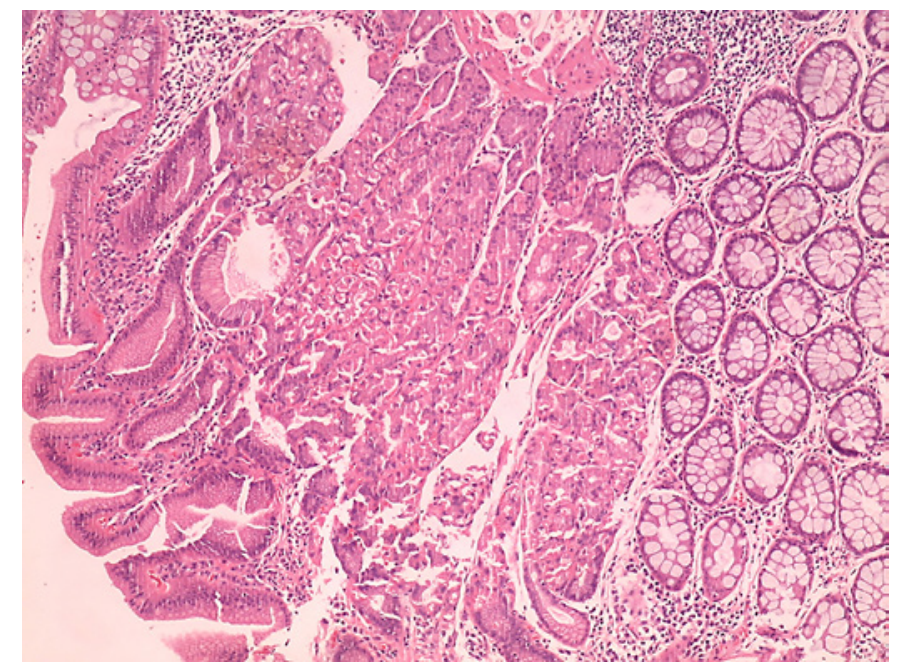

Fig. 2. Panoramic view of gastric oxyntic mucosa sharply demarcated from colonic mucosa. HE. $\times 200$.

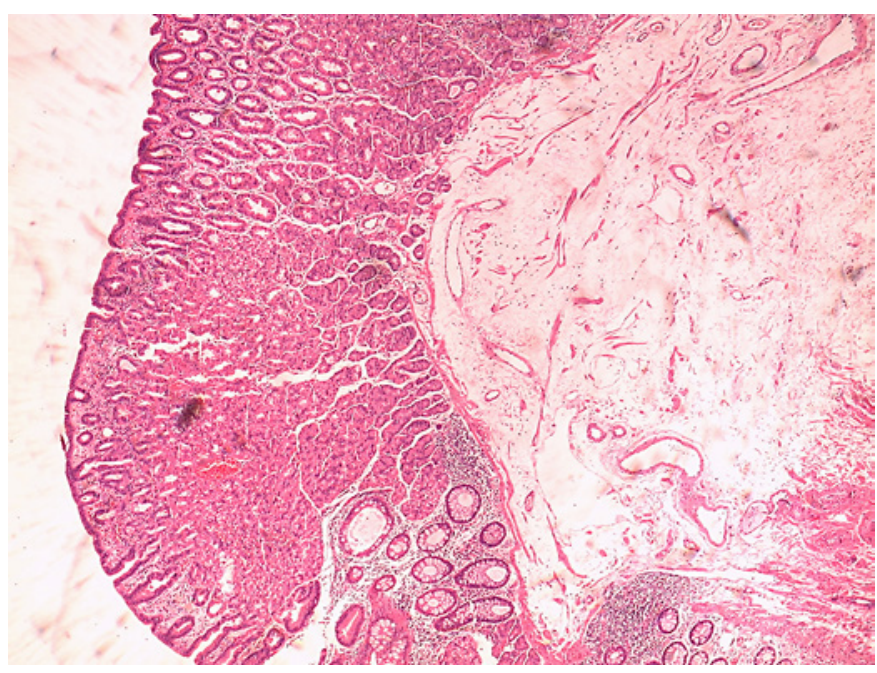

Fig. 3. Core of the polyp showing delicate vascular network in loose connective tissue. HE. $\times 200$.

\section{Acknowledgements}

The authors want to thank Mr. Jose Eduardo Matos (photographer) for his technical assistance.

\section{Statement of Ethics}

This study did not require informed consent or review/approval by the ethics committee.
Duran Alvarez/Tafur Sanchez 


\section{Disclosure Statement}

All authors have read and approved the manuscript and declare that they have no conflict of interests.

\section{Author Contributions}

M.A.D.A.: design, search, drafting the manuscript including histologic images. C.N.T.S.: management of the patient, search, and endoscopic image.
References
1 Srinivasan R, Loewenstine H, Mayle JE. Sessile polypoid gastric heterotopia of rectum: a report of 2 cases and review of the literature. Arch Pathol Lab Med. 1999 Mar;123(3):2224.

2 Fenoglio-Preiser CM. Gastrointestinal Pathology. Wolters Kluwer ed. Philadelphia; 2008. pg. 857-8.
3 Murray FE, Lombard M, Dervan P, Fitzgerald RJ, Crowe J. Bleeding from multifocal heterotopic gastric mucosa in the colon controlled by an H2 antagonist. Gut. 1988 Jun;29(6):848-51.

4 Ko H, Park SY, Cha EJ, Sohn JS. Colonic adenocarcinoma arising from gastric heterotopia: a case study. Korean J Pathol. 2013 Jun; 47(3):289-92. 